\title{
CEO Turnover after Acquisitions: Are Self-interested Bidders Fired?
}

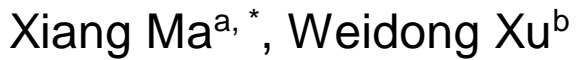 \\ School of Management, Zhejiang University, Hangzhou 310058, China \\ amaxiang@zju.edu.cn, bweidxu@zju.edu.cn
}

Keywords: Mergers and acquisitions, CEO compensation, Agency problems, Corporate governance, CEO turnover.

\begin{abstract}
We examine the relation between the abnormal compensation acquirer chief executive officer (CEO) obtained and the probability of CEO turnover. Using a sample of 306 acquisitions made by Chinese listed firms during 2006 to 2010, we document a significant positive relation between the abnormal compensation changes and the likelihood of CEO turnover. Though CEO can extract substantial pecuniary benefits from acquisitions, large increases in abnormal compensation is a negative revelation of CEO preference, CEOs who make self-interested acquisitions are significantly more likely to be replaced within 5 years of the M\&A completion.
\end{abstract}

\section{Literature review and hypothesis}

In the literature on mergers and acquisitions (M\&A), the majority of studies concluded that M\&A fail to add value to the acquirer (Eckbo (2009) ${ }^{[1]}$, Bhaumik and Selarka (2012) ${ }^{[2]}$ ). A dominant explanation is the well-known agency conflict between managers and owners, whereby managers undertake value-destroying acquisitions to reap personal benefits at the expense of shareholders (Jensen (1986) ${ }^{[3]}$ ). A natural question is whether bad bidders are fired, Scholten (2005) ${ }^{[4]}$ conclude that being disciplined for making a poor acquisition is more a function of internal discipline than the workings of the takeover market. Lehn and Zhao (2006) ${ }^{[5]}$ find a significant inverse relation between bidder returns and the likelihood of CEO turnover, bad bidders are disciplined by both internal governance and external control mechanisms.

Further research indicates that the labor market attaches value to CEO quality information in the context of acquisition decisions. Lehn and Zhao (2006) ${ }^{[5]}$ find that bidders who cancel acquisitions having a negative market response at announcement are rewarded via a lower turnover probability subsequent to deal failure. Jacobsen $(2014)^{[6]}$ focus on a sample of acquisition bids that are withdrawn because the transaction price becomes too expensive, and show that CEOs in this sample are significantly less likely to be fired.

Another strand of M\&A research reports that CEOs engage in acquisitions experience large increase in compensation despite having poor acquisition performance, which is consistent with the view that managers undertake value-destroying acquisitions to extract personal benefits at shareholder expense. Bliss and Rosen (2001) ${ }^{[7]}$ find that CEO pay generally increases even if mergers cause the acquiring bank's stock price to decline. Grinstein and Hribar (2004) ${ }^{[8]}$ show that M\&A bonuses are not related to deal performance. Harford and $\mathrm{Li}(2007){ }^{[9]}$ find that acquirer CEOs are significantly better off due to substantial new stock and option grants following acquisitions, and CEO pay becomes detached from performance after an acquisition. Yim (2013) ${ }^{[10]}$ demonstrate that acquisitions are accompanied by large increases in CEO compensation, which create strong financial incentives for CEOs to pursue acquisitions earlier in their career. Fich et al. (2014) ${ }^{[11]}$ find that beyond compensation for increases in firm size or complexity, CEOs are rewarded for their deal-making activities.

The private benefits CEO extracted through M\&A provide an opportunity to examine the effectiveness of corporate governance mechanisms. Since a CEO who has a high preference for private benefits would use company resources in an inefficient manner and indulge in perquisite-consumption and empire-building behaviors at the expense of shareholders, if the corporate governance mechanisms 
could gather valuable information regarding CEO preference from the abnormal benefits acquirer CEOs received, then the CEO preference information should be utilized in future career decisions involving the CEO, those CEOs with higher preference for private benefits are expected to be replaced with greater frequency. Thus we expect a positive relation between the abnormal private benefits and the probability of CEO turnover.

The remainder of the paper is organized as follows. Section 2 describes the sample and data. Section 3 explains empirical design and methods. Section 4 presents empirical results, and Section 5 provides concluding remarks. Section 6 presents references.

\section{Sample and data}

We create a panel data set of CEOs from 2005 to 2011 using information from China Stock Market and Accounting Research (CSMAR) database and proxy statement. This data set includes all publically traded Chinese firms listed on the Shanghai and Shenzhen Stock Exchanges. Since 2005, Chinese listed firms are required to report each individual board member's and top management's total compensation as the sum of salary, bonus, stipends, and other benefits. Meanwhile, the Chinese Securities Regulation Committee (CSRC) provided a framework to introduce equity incentives in 2005, firms are required to disclose information on stock options from 2006.

The sample of mergers and acquisitions is also from CSMAR database. A transaction is included in the sample if it satisfies the following criteria: (1) The merger or acquisition is announced between January 1, 2006 and December 31, 2010; (2) The acquirer is a publicly traded company, the target can be publicly traded or private firm; (3) The status of the deal is completed; (4) The transaction value is at least $5 \%$ of the acquirer's market capitalization at the end of the fiscal year before the deal was announced; (5) The acquiring firm's stock price data and CEO compensation data is available. These criteria result in an initial sample of 394 mergers and acquisitions.

Three hundred and sixteen different acquiring firms account for the 394 mergers and acquisitions. Of these, 65 firms completed more than one acquisition during the sample period, and in 50 of the 65 firms, the same CEO completed each acquisition. For these 50 firms, we include the largest merger or acquisition during the period in the sample. Of the remaining 15 firms, different CEO effected the different acquisitions. For these firms, we include the largest acquisition made by each of the CEOs. This results in a sample of 331 mergers and acquisitions.

Other data, including accounting data, stock price data, corporate governance data and CEO turnover data are also obtained from the CSMAR database.

\section{Empirical design and method}

\subsection{Definition of CEO turnover}

Our secification of CEO turnover is similar to Scholten (2005) ${ }^{[4]}$, Lehn and Zhao (2006) ${ }^{[5]}$, Jacobsen (2014) ${ }^{[6]}$. If the CEO is reported as fired, forced from his or her position, or leaves for unspecified reasons, then the turnover is classified as disciplinary. If the CEO is under the age of 60 and the reason for departure is unrelated to death, the CEO is also classified as experiencing a disciplinary turnover. We define a dummy variable for CEO turnover that takes the value of one if the acquiring firm's CEO is replaced within 5 years of the merger or acquisition's completion, and zero otherwise.

\subsection{The abnormal private benefits of acquirer CEOs}

In order to get the abnormal private benefits CEO obtained, we first construct a model of normal compensation by regressing the natural log of CEO total pay on characteristics identified in the compensation literature (e.g., firm size, performance, CEO age, etc.), we estimate the model based on a panel data set that includes all listed firm's CEOs from 2005 to 2011. Fixed effects models are used to get the residual (unexplained or abnormal compensation) for each CEO each year.

Then we match each acquiring firm to a non-merging firm that: (1) does not conduct a merger or acquisition in a five year window centered on the merger completion year; (2) is in the same industry as 
the acquirer in the year prior to merger announcement; (3) has total assets of 50-150\% of the acquirer at the end of the fiscal year before the deal was announced; (4) has ROA of 50-150\% of the acquirer in the year prior to merger announcement; (5) has CEO compensation of 50-150\% of the acquirer in the year prior to merger announcement; (6) has the closet unexplained compensation to the acquirer CEO in the year prior to merger announcement. This procedure yields 306 matched firms for the 331 acquirers, so our final sample consists of 306 acquisitions.

The abnormal private benefits of acquirer CEOs is defined as the changes of residual of acquirers from the year prior to merger announcement to the merger completion year (i.e., the difference between the abnormal compensation of acquirer in completion year and the abnormal compensation of acquirer in the year prior to merger announcement) minus the corresponding changes of residual of matched firms, we call it abnormal compensation changes ( $\triangle$ Abnormal).

The abnormal compensation changes measures the benefits CEO obtained beyond compensation for merger-related increases in firm size, changes in firm performance, and merger-unrelated changes in firm and CEO characteristics, meanwhile takes what would have happened if the acquirers had not pursued the acquisition into consideration.

\subsection{Empirical design}

Table 1. Variable definitions.

\begin{tabular}{|c|c|}
\hline Variable & Definition \\
\hline $\begin{array}{l}\text { Relative size of } \\
\text { target }\end{array}$ & $\begin{array}{l}\text { The ratio of the transaction value to the acquirer's market capitalization at the end of } \\
\text { the fiscal year before the deal was announced. }\end{array}$ \\
\hline Stock & $\begin{array}{l}\text { Dummy variable that equals to one if the payment for the deal is stock or a } \\
\text { combination of stock and cash, and equals to zero otherwise. }\end{array}$ \\
\hline CAR [0] & $\begin{array}{l}\text { Abnormal return on the announcement date, estimates from the standard event study } \\
\text { methodology. }\end{array}$ \\
\hline CAR $[-1,1]$ & $\begin{array}{l}\text { Three-day cumulative abnormal returns around the announcement date, estimates } \\
\text { from the standard event study methodology. }\end{array}$ \\
\hline CAR $[-5,5]$ & $\begin{array}{l}\text { Ten-day cumulative abnormal returns around the announcement date, estimates from } \\
\text { the standard event study methodology. }\end{array}$ \\
\hline Post-BHAR & $\begin{array}{l}\text { Market-adjusted buy-and-hold returns from the announcement date to either } 3 \text { years } \\
\text { after the announcement or the month in which the acquirer CEO is replaced, } \\
\text { whichever comes the first. }\end{array}$ \\
\hline Post-ROA & $\begin{array}{l}\text { The mean industry-adjusted return on assets over the } 3 \text { years after the deal } \\
\text { completion, or over the completion year to the fiscal year prior to the CEO turnover } \\
\text { announcement if the CEO is replaced. }\end{array}$ \\
\hline CEO age & Age of the CEO at the time of the deal completion. \\
\hline CEO tenure & $\begin{array}{l}\text { Length of time that the CEO held the position of CEO at the time of the deal } \\
\text { completion, in years. }\end{array}$ \\
\hline$\Delta$ CashPay & $\begin{array}{l}\text { The changes of cash pay from the year prior to deal announcement to the deal } \\
\text { completion year. }\end{array}$ \\
\hline$\Delta$ TotalPay & $\begin{array}{l}\text { The changes of total pay from the year prior to deal announcement to the deal } \\
\text { completion year. }\end{array}$ \\
\hline$\Delta$ Residual & $\begin{array}{l}\text { The changes of unexplained compensation of acquirers from the year prior to deal } \\
\text { announcement to the deal completion year. }\end{array}$ \\
\hline$\Delta$ Abnormal & $\begin{array}{l}\text { The changes of unexplained compensation of acquirers minus the corresponding } \\
\text { changes of unexplained compensation of matched firms. }\end{array}$ \\
\hline
\end{tabular}

To examine the relation between the abnormal compensation changes and subsequent CEO turnover, we estimate a logit regression that models the probability that a CEO will experience a turnover event in the five years following the deal completion date. The following independent variables are included in the regression: the abnormal compensation changes ( $\triangle$ Abnormal), $C E O$ age (CEO age) and tenure (CEO tenure), bidder announcement returns (CAR [-1, 1]), relative size of the target (Relative size of target), a stock in payment dummy (Stock), market-adjusted post-deal buy-and-hold abnormal returns 
(Post-BHAR) and industry-adjusted post-deal ROA (Post-ROA). A complete description of all variables can be found in Table 1 .

\section{Empirical results}

\subsection{Sample descriptive statistics}

Table 2 reports the mean and median values of relevant variables for the full sample of 306 completed deals, and for two subsamples, namely, the 163 deals in which the acquiring firm's CEOs are replaced within 5 years of the merger or acquisition completion, and the remaining 143 deals in which the acquiring firm's CEOs are not replaced. A complete description of all variables can be found in Table 1.

Table 2. Sample descriptive statistics

\begin{tabular}{|c|c|c|c|c|c|c|c|c|}
\hline \multirow{2}{*}{ Variable } & \multicolumn{2}{|c|}{ Total sample } & \multicolumn{2}{c|}{ CEO turnover } & \multicolumn{2}{c|}{ No CEO turnover } & \multicolumn{2}{c|}{ Tests for differences } \\
\cline { 2 - 10 } & Mean & Median & Mean & Median & Mean & Median & t-Test & Wilcoxon \\
\hline $\begin{array}{c}\text { Relative size } \\
\text { of target }\end{array}$ & 0.33 & 0.11 & 0.44 & 0.12 & 0.21 & 0.09 & $2.53^{* *}$ & $1.78^{*}$ \\
\hline Stock & 0.23 & 0 & 0.28 & 0 & 0.17 & 0 & $2.23^{* *}$ & $2.22^{* *}$ \\
\hline CAR [0] & $1.01 \%$ & $0.22 \%$ & $1.11 \%$ & $0.28 \%$ & $0.90 \%$ & $0.20 \%$ & 0.35 & 0.37 \\
\hline CAR [-1,1] & $2.53 \%$ & $0.46 \%$ & $2.89 \%$ & $0.39 \%$ & $2.12 \%$ & $0.57 \%$ & 0.69 & 0.39 \\
\hline CAR [-5,5] & $4.54 \%$ & $1.20 \%$ & $4.95 \%$ & $1.21 \%$ & $4.07 \%$ & $1.19 \%$ & 0.45 & 0.38 \\
\hline Post-BHAR & $33.56 \%$ & $5.47 \%$ & $35.17 \%$ & $0.03 \%$ & $31.72 \%$ & $15.77 \%$ & 0.33 & -0.88 \\
\hline Post-ROA & $-1.19 \%$ & $-0.92 \%$ & $-2.19 \%$ & $-1.61 \%$ & $-0.05 \%$ & $-0.09 \%$ & $-3.35^{* * *}$ & $-2.98^{* * *}$ \\
\hline CEO age & 46.1 & 45 & 45.8 & 45 & 46.4 & 46 & -1.00 & -0.55 \\
\hline CEO tenure & 3.04 & 2.19 & 2.66 & 1.75 & 3.47 & 3 & $-2.61^{* * *}$ & $-2.88^{* * *}$ \\
\hline$\Delta$ CashPay & 119178.9 & 39547.1 & 167074.4 & 77119.3 & 64584.6 & 20631.9 & $2.80^{* * *}$ & $3.95^{* * *}$ \\
\hline$\Delta$ TotalPay & 141435.5 & 42464.3 & 208856.9 & 80145.7 & 64584.6 & 20631.9 & $2.77 * * *$ & $4.25^{* * *}$ \\
\hline$\Delta$ Residual & 0.096 & 0.024 & 0.233 & 0.182 & -0.059 & -0.091 & $5.62^{* * *}$ & $5.77 * * *$ \\
\hline$\Delta$ Abnormal & 0.063 & 0.014 & 0.193 & 0.132 & -0.084 & -0.076 & $7.88^{* * *}$ & $8.04 * * *$ \\
\hline
\end{tabular}

This table reports the mean and median values of relevant variables for the sample of 306 completed mergers and acquisitions and two subsamples. The CEO turnover sample consists of 163 deals that acquiring firm's CEOs are replaced within 5 years of the merger or acquisition completion. The remaining 143 deals are included in the "No CEO turnover" sample. Variables are defined in Table 1. All RMB values are measured in the 2011 constant RMB. ***, **, and * denote statistical significance at the $1 \%, 5 \%$, and $10 \%$ level based on T-tests for the differences in mean values and Wilcoxon tests for the differences in median values.

For the entire sample, the transaction value, on average, is $33 \%$ of the market value of the corresponding acquiring firm. The mean (median) relative size of target is significantly higher for firms with CEO turnover than for firms without turnover. On average, $23 \%$ of the sample firms use stock or a combination of stock and cash as a method of payment for the merger or acquisition. The frequency of using stock as a method of payment is significantly higher for firms with CEO turnover (28\%) than firms without CEO turnover (17\%).

While prior studies generally find that the acquirer announcement period returns are negative, and the negative bidder returns are more pronounced for firms with CEO turnover than for firms without turnover, our sample exhibits a completely different results in Chinese context. The mean (median) announcement returns are positive and statistically significant for the entire sample of acquisitions, vary from $1.01 \%(0.22 \%)$ on day 0 to $4.54 \%(1.20 \%)$ over the [-5,5] window. Announcement period returns are also positive and statistically significant for firms with CEO turnover and without CEO turnover, and more importantly, no significant difference exists in either the mean or median announcement returns over several windows for between firms with CEO turnover and those without CEO turnover. It appears that the initial stock market reaction to the deal is generally positive, and it's not an effective estimate of whether the acquisition serves the interest of shareholders in Chinese stock 
market.

For the entire sample, the mean (median) buy-and-hold abnormal return after the merger (Post-BHAR) is $33.56 \%(5.47 \%)$. Neither the difference in means nor the medians is significant between the two subsamples. Industry-adjusted mean (median) post-merger ROA (Post-ROA) is $-2.19 \%(-1.61 \%)$ for firms with CEO turnover versus $-0.05 \%(-0.09 \%)$ for firms without CEO turnover. The difference in both the mean and median values is significant at the 0.01 level.

The mean age of CEOs is 46.1 for the full sample. Little difference exists in the mean and median CEO age across the two subsamples. The mean and median tenure of CEOs is significantly shorter for firms with CEO turnover than firms without CEO turnover.

\subsection{The abnormal compensation changes}

CEOs that are subsequently replaced experience significantly larger increases in cash pay and total pay. For firms with CEO turnover, mean (median) $\triangle$ CashPay is 167074.4 (77119.3), and mean (median) $\triangle$ CashPay is 64584.6 (20631.9) for firms without CEO turnover. The difference in both the mean and median values is significant at the 0.01 level. Similar results obtain for the changes of total pay ( $\Delta$ TotalPay).

For the entire sample, the mean (median) change of unexplained compensation of acquirers ( $\triangle$ Residual) is $0.096(0.024)$. The mean and median $\Delta$ Residual is significantly larger for firms with CEO turnover than firms without CEO turnover at the 0.01 level. After considering what would have happened if the acquirers had not pursued the acquisition, the mean (median) abnormal compensation changes ( $\triangle$ Abnormal) is $0.063(0.014)$ for the full sample. For firms with CEO turnover, mean (median) $\triangle$ Abnormal is $0.193(0.132)$, and mean (median) $\triangle$ Abnormal is $-0.084(-0.076)$ for firms without CEO turnover. The difference in both the mean and median values is significant at the 0.01 level.

Combined, CEOs that are subsequently replaced experience large increases in compensation and abnormal compensation, while CEOs that are not replaced experience decreases in abnormal compensation and small increases in compensation. Our results indicate that though acquisitions serve as opportunities for the CEOs to renegotiate their compensation, CEOs pay a price, in the form of their jobs, for making self-interested acquisitions.

\subsection{Logit estimates of the likelihood of CEO turnover}

Table 3. Logit regression of the probability that the acquiring firm's CEO is replaced

\begin{tabular}{|c|c|c|c|}
\hline & $(1)$ & $(2)$ & $(3)$ \\
\hline \multirow{2}{*}{$\Delta$ abnormal } & $0.7144^{* * *}$ & $0.6838^{* * *}$ & $0.6890^{* * *}$ \\
& $(0.000)$ & $(0.000)$ & $(0.000)$ \\
\hline \multirow{2}{*}{ CEO age } & & 0.0001 & 0.0009 \\
& & $(0.976)$ & $(0.840)$ \\
\hline \multirow{2}{*}{ CEO tenure } & & $-0.018^{*}$ & -0.015 \\
& & $(0.071)$ & $(0.108)$ \\
\hline \multirow{2}{*}{ CAR [-1,1] } & & -0.223 & -0.219 \\
& & $(0.495)$ & $(0.493)$ \\
\hline \multirow{2}{*}{ Relative size of target } & & 0.0756 & 0.0659 \\
& & $0.206)$ & $(0.280)$ \\
\hline Stock & & 0.1112 & $0.1331^{*}$ \\
& & $(0.141)$ & $(0.076)$ \\
\hline \multirow{2}{*}{ Post-BHAR } & & & 0.0224 \\
& & & $(0.438)$ \\
\hline \multirow{2}{*}{ Post-ROA } & & & $-1.889^{* * *}$ \\
& & $0.000)$ \\
\hline Pseudo-R ${ }^{2}$ & 0.1467 & 0.175 & 0.2104 \\
\hline Number of observations & 306 & 306 & 306 \\
\hline
\end{tabular}

To more thoroughly explore the relation between the abnormal compensation changes and the probability of subsequent CEO turnover, a logit model is employed. Table 3 presents the results from 
the estimates. The coefficients are estimated as the marginal effect on the probability of turnover of an increase in the independent variable.

This table reports the results from a logit regression that models the probability a CEO will experience a turnover event controlling for CEO characteristics, deal characteristics and firm performance. A complete description of variables can be found in Table 1. The coefficients are estimates of the marginal effect on the probability of turnover of an increase in the independent variable. p-Values are shown in parentheses. $* * *, * *, *$ indicate significance at the $1 \%, 5 \%$, and $10 \%$ level, respectively.

The coefficient on $\Delta \mathrm{Abnormal}$ is positive and significant at the 0.01 level in all the equations. This evidence is consistent with the hypothesis that CEOs who make self-interested acquisitions are more likely to be replaced. The coefficient on CAR $[-1,1]$ is negative but is not significant ${ }^{1}$, confirming that the initial stock market reaction is not an effective estimate of whether the acquisition serves the interest of shareholders in Chinese stock market. The coefficient on CEO tenure is negative and significant in equation 2, indicating that longer CEO tenure is associated with a lower probability of turnover. The Stock dummy has a positive and significant coefficient in equation 3, indicating that acquirer CEOs who use stock as a method of payment face a higher probability of being replaced. The coefficient on post-merger ROA (Post-ROA) is negative and significant at the 0.01 level, indicating that post-merger operating performance is associated with the probability of CEO turnover. Regression results in Table 3 provide further evidence that corporate governance mechanisms discipline CEOs that have made a self-interested merger or acquisitions.

\section{Conclusion}

Previous research shows that acquirer CEOs receive large increase in compensation despite having poor acquisition performance, which is consistent with the view that managers undertake value-destroying acquisitions to extract private benefits at shareholder expense. This paper examine whether corporate governance mechanisms discipline managers who make self-interested acquisitions.

Based on a sample of 306 acquisitions made by Chinese listed firms during 2006 through 2010, we show that a significant positive relation exists between abnormal compensation changes and the likelihood of CEO turnover. Although M\&A provide opportunities for acquirer CEOs to obtain substantial compensation benefits, large increases in abnormal compensation convey negative signal regarding $\mathrm{CEO}$ preference, managers who make self-interested acquisitions face a significantly higher probability of being replaced. CEOs should make a tradeoff between short-term pecuniary benefits and long-run career concerns.

Inconsistent with prior studies, we do not find a significant inverse relation between bidder returns and CEO turnover, indicating that the initial stock market reaction is not an effective estimate of whether the acquisition serves the interest of shareholders in Chinese stock market.

\section{References}

[1] Eckbo, B. E. Bidding strategies and takeover premiums: A review. Journal of Corporate Finance 15 (2009) 149-178.

[2] Bhaumik, S K, and E. Selarka. Does ownership concentration improve M\&A outcomes in emerging markets? : Evidence from India. Journal of Corporate Finance 18 (2012) 717-726.

[3] Jensen, M C. Agency Costs of Free Cash Flow, Corporate Finance, and Takeovers. American Economic Review 76 (1986) 323-329.

[4] Scholten, R. Investment Decisions and Managerial Discipline: Evidence from the Takeover Market. Financial Management 34 (2005) 35-61.

[5] Lehn, K M., M. Zhao. CEO Turnover after Acquisitions: Are Bad Bidders Fired? The Journal of Finance 61 (2006) 1759-1811.

\footnotetext{
${ }^{1}$ We replicate the logit regression based on CARs measured over different windows, the results are qualitatively similar.
} 
[6] Jacobsen, S. The death of the deal: Are withdrawn acquisition deals informative of CEO quality? Journal of Financial Economics 114 (2014) 54-83.

[7] Bliss, R T, R. J. Rosen. CEO compensation and bank mergers. Journal of Financial Economics 61 (2001) 107-138.

[8] Grinstein, Y, P. Hribar. CEO compensation and incentives: Evidence from M\&A bonuses. Journal of Financial Economics 73 (2004) 119-143.

[9] Harford, J, Li. K. Decoupling CEO Wealth and Firm Performance: The Case of Acquiring CEOs. The Journal of Finance 62 (2007) 917-949.

[10] Yim, S. The acquisitiveness of youth: CEO age and acquisition behavior. Journal of Financial Economics 108 (2013) 250-273.

[11] Fich, E., Starks, L., Yore, A., CEO deal-making activities and compensation. Journal of Financial Economics 114 (2014) 471-492. 